\title{
EDITORIAL
}

\section{Finding Meaning in Education}

\author{
Tunku Badariah Tunku Ahmad ${ }^{1}$
}

As educators we often ask ourselves, "Is there meaning in what we teach? If there is, what is that meaning? And do students see the meaning we see? The meaning we want them to see?" Perhaps for many of us teachers and educators, we struggle to build meaning into our teaching, to give context to content, to make learning relevant, and to make students' coming to class not in vain.

When students" "see" the meaning of classroom content in daily life — how it might help them in their various endeavors - that is when we can consider our teaching successful. That perhaps, education has taken place.

Finding ways and means of building meaning into teaching is a lifelong struggle for many educators. Some find it in the methods they use to deliver content; some may employ technology tools. Others may reach out to parents and the wider community to help forge this meaning.

In this issue, we present some of the works representative of the ongoing effort to make teaching and learning, hence education, meaningful. In Manar Eissa and Madihah Khalid's work, meaning is sought through the use of Qur'anic and Prophetic Teaching Methods (QPTMs). The reason behind the use of these methods is to develop sound moral character and life skills among school students. Education devoid of moral character is education in vain. Indeed, our beloved Prophet Muhammad [peace be upon him], had said: "I have only been sent to perfect good moral character." Thus, our task as educators (and perhaps, educational researchers as well) is to continue in this role and tradition.

Along a similar aim, Shahini and Nouri look at ESL students' philosophical thinking, which they believe can be molded through philosophy-based language teaching (PBLT). It is their contention that language educators regularly engage L2 learners in philosophically-inspired discussions in liberal, democratized classrooms (Shahini \& Nouri, 2018, p. 31) to open up the learners' minds regarding the social and material world around them. PBLT boosts students' thinking and reasoning in a fashion that is not so different from what the Holy Qur'an urges mankind to do:

\footnotetext{
${ }^{1}$ Kulliyyah of Education, International Islamic University Malaysia. Email: tbadariah@iium.edu.my
} 
"And We revealed to you the message that you may make clear to the people what was sent down to them and that they might give thought." (Surah An-Nahl, verse 44)

“Have they not pondered upon themselves?"(Surah Ar-Rum, verse 8)

"Indeed, the worst of living creatures in the sight of Allah are the deaf and dumb who do not use reason. (Surah Al-Anfal, verse 22)

Education is meaningful when it can help us address life's many issues and challenges. Education has many truths that depend on the context. The truths and realities in some parts of the world, like Nigeria, are certainly different from what is encountered elsewhere. Abdullahi and Salisu point this out in their exploration of the role played by Arabic language in addressing security issues created by entities like the Boko Haram. Members of such groups tend to be speakers of Arabic; thus being able to speak Arabic is an advantage for Nigerians confronted with security issues, especially those in the military and paramilitary forces who struggle daily to remove harm from public spheres.

What and where is the role of technology in all this quest for meaning, we might ask. In finding relevance in education? Because of its very intrusive nature, it is important that educators see how technology can be turned into a "friend" rather than an "enemy". So instead of fighting technology, why not use it to promote lifelong learning? Such is one of the many affordances of Massive Open Online Courses (MOOCs), which is examined in Tahiru and Kamalluddeen's research on MOOC acceptance and readiness where they found students' professing the usefulness of MOOCs and an intention to use them for continued learning. Although unfamiliar with the platform, students could see meaning in the use of MOOCs.

And of course, the effort to establish meaning in education cannot be done by educators alone. Parents must be in the bandwagon as well. Education for children is a journey and an experience whose success depends on the positive collaboration among teachers, schools, parents and the community. Thartori discovered this well in her parental involvement research among Albanian parents.

Meaning changes as we mature as teachers and educators. What we found meaningful yesterday may no longer be relevant today. So we keep going in our search and quest for meaning, and in our effort to establish it in our classrooms. 